Editorial

\title{
Corrupção e prosperidade na grande colméia
}

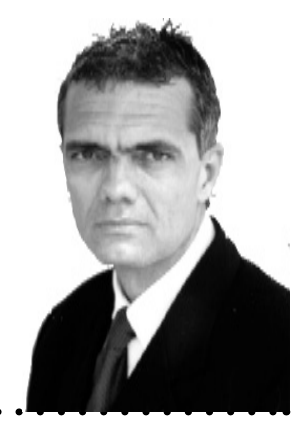

\section{Marco Antonio Guimarães da Silva} marco@atlanticaedu.com.br

Assim o vicio em cada parte vivia, Mas o todo, um paraíso constituía; Temido na guerra, na paz incensado; Pelos estrangeiros eram respeitados; E, de riquezas e vida abundante, Entre as colméias era a preponderante. Tais eram as bênçãos daquele estado; Seus crimes tomavam-no abastado; $\mathrm{E}$ a virtude, que como a politicagem Aprendera bastante malandragem Tomara-se pela feliz influência, Amiga do vicio; por consequência, O pior elemento em toda a multidáo Realizava algo para o bem da nação.

$\mathrm{O}$ ano chega ao fim. Tinha planos de fugir a regra e fazer um editorial natalino, sem as críticas e reflexóes do nosso cotidiano. Não consigo. Diante de tamanha riqueza de fatos na área da corrupção, faço uma releitura da Fabula das Abelhas, de onde retirei a epígrafe que abre o presente texto, ensaiando uma tentativa de abordar a atual situação pelo seu avesso ético.

O autor da fábula, Bernard de Mandeville (1670-1733) advoga que, se a harmonia de uma partitura é uma combinaçáo de resultados de sons diferentes e, às vezes, opostos entre si, do mesmo modo, uma sociedade, que ele compara ao enxame de abelhas - justamente por seguir caminhos diversificados - termina por se complementar. Essa fábula dá amparo ao provérbio: não há mal que para bem não venha. Para Mandeville, os benefícios públicos só provem do mal, ou seja, dos vícios privados. Quanto mais cheios de vícios estejam os componentes de um grupo, maior será a prosperidade desse mesmo grupo. Os vícios particulares dão enorme contribuição para a felicidade pública e os mais corruptos ajudam ao bem comum. O egoísmo, a avareza, a hipocrisia contribuíram mais para o progresso do que a generosidade, a piedade ou o altruísmo. O vício é positivo, a virtude, negativa. Obviamente, Mandeville recebeu criticas - destaque para Hume (iluminismo escocês 1711-1776) - mas, de certa forma, a obra contribuiu para fortalecimento de uma moral laica, livre da moral cristâ. Alguns autores, que se inclinavam a defender condutas contrárias à ortodoxia (Rousseau, Montesquieu, Sade, etc) também foram influenciados.
Voltemos às abelhas e partamos para a nossa realidade, amparada aqui em um quadro puramente ficcional. Somos muitos milhóes de homens abelhas e, claro, formamos uma grande colméia, com uma organização, a princípio, bem distinta dos insetos abelhas. No entanto, podemos dizer que, tal como numa colméia, existem os homens abelhas-sociais, a grande maioria, e os homens-abelhas solitários, uma minoria que foge ao padrão. Ambos formam o contingente de homens-abelhas operários. Aqui, o homem abelha-rainha não necessariamente é uma mulher. Os operários trabalham duro, pagam impostos e geram o que chamamos na colméia de a coisa. Além dos homens abelhas operários, há outras classes e sub-classes, devidamente distribuídas nas esferas federais, estaduais e municipais da colméia. $\mathrm{O}$ homem abelha-rainha e essas classes e sub-classes, que são eleitas pelos homens abelhas operários, dedicam todo os seu tempo ao gerenciamento da coisa, que, de tâo farta, consegue manter e dar prosperidade à colméia e ainda enriquece ilicitamente a quase todos os que a gerenciam. Os homens abelhas operários sociais sabem de toda a traquinagem, mas também têm lá a sua porção vil. Cometem ilícitos menores, que, aos seus olhos, são pequenos demais para serem considerados como tal: subornam a abelha guarda da esquina, tentam fraudar concursos, prevaricam, fazem peculato, envolvem-se em concussão, transformam-se em vespas furiosas e assassinas diante um simples jogo desportivo, etc. E, assim, em um mar de indulgencias recíproco, levam a vida.

Haveria alguma possibilidade de alteraçâo dessa realidade? É a pergunta que fariam a si mesmo os homens abelhas solitários, aqueles que não compartilham da safadeza vigorante. Sabem que a questáo tem um complexo equacionamento e que depende de duas circunstâncias: a difícil regeneração dos homens-abelhas sociais, com a necessidade de várias geraçôes para que os hábitos culturais profundamente enraizados se alterassem, e as impossíveis mudanças de atitude do homem abelha rainha e das classes e subclasses cada vez mais ávidas pela coisa

Talvez o mais desanimador e desesperador esteja na possível degradação dos homens abelhas solitários, já que os princípios éticos que os regem podem sofrer a influência do comportamento social majoritariamente vigente.

Para observador externo, a situação da colméia é difícil e parece que a cada dia que passa seus habitantes descem mais um degrau para inferno.

E isso é tudo. Não se desespere agora, porque pode ficar pior!

Feliz Natal e um decente Ano novo. 